\title{
Diabetes and Covid-19 among hospitalized patients in Saudi Arabia: a single-centre retrospective study
}

\author{
Abdullah M. Alguwaihes ${ }^{1 *}\left(\mathbb{0}\right.$, Mohammed E. Al-Sofiani ${ }^{1,2,3}$, Maram Megdad4 ${ }^{4}$, Sakhar S. Albader ${ }^{5}$, \\ Mohammad H. Alsari ${ }^{5}$, Ali Alelayan, Saad H. Alzahrani ${ }^{6}$, Shaun Sabico ${ }^{7}$, Nasser M. Al-Daghri ${ }^{7}$ \\ and Anwar A. Jammah ${ }^{1}$
}

\begin{abstract}
Background: Information on the clinical characteristics and outcomes of hospitalized Covid-19 patients with or without diabetes mellitus (DM) is limited in the Arab region. This study aims to fill this gap.

Methods: In this single-center retrospective study, medical records of hospitalized adults with confirmed Covid-19 [RT-PCR positive for SARS-CoV2] at King Saud University Medical City (KSUMC)-King Khaled University Hospital (KKUH), Riyadh, Saudi Arabia from May to July 2020 were analyzed. Clinical, radiological and serological information, as well as outcomes were recorded and analyzed.

Results: A total of 439 patients were included (median age 55 years; $68.3 \%$ men). The most prevalent comorbidities were vitamin D deficiency (74.7\%), DM (68.3\%), hypertension (42.6\%) and obesity (42.2\%). During hospitalization, 77 out of the 439 patients (17.5\%) died. DM patients have a significantly higher death rate ( $20.5 \%$ versus $12.3 \% ; p=0.04)$ and lower survival time $(p=0.016)$ than non-DM. Multivariate cox proportional hazards regression model revealed that age [Hazards ratio, HR 3.0 (95\% confidence interval, $\mathrm{Cl} 1.7-5.3) ; \mathrm{p}<0.001$ ], congestive heart failure [adjusted HR 3.5 (Cl 1.4-8.3); $p=0.006$ ], smoking [adjusted HR 5.8 (Cl 2.0-17.2); $p<0.001$ ], $\beta$-blocker use [adjusted HR 1.7 (Cl 1.0-2.9); $p=0.04$ ], bilateral lung infiltrates [adjusted HR 1.9 (Cl 1.1-3.3); $p=0.02$ ], creatinine $>90 \mu \mathrm{mol} / \mathrm{l}$ [adjusted HR 2.1 (Cl 1.3-3.5); $p=0.004$ ] and 25(OH)D $<12.5 \mathrm{nmol} /$ l [adjusted HR 7.0 (Cl 1.7-28.2); $p=0.007$ ] were significant predictors of mortality among hospitalized Covid-19 patients. Random blood glucose $\geq 11.1 \mathrm{mmol} / \mathrm{I}$ was significantly associated with intensive care admission [adjusted HR 1.5 (Cl 1.0-2.2); $p=0.04$ ], as well as smoking, $\beta$-blocker use, neutrophil $>7.5$, creatinine $>90 \mu \mathrm{mol} / \mathrm{l}$ and alanine aminotransferase $>65 \mathrm{U} / \mathrm{l}$.

Conclusion: The prevalence of DM is high among hospitalized Covid-19 patients in Riyadh, Saudi Arabia. While DM patients have a higher mortality rate than their non-DM counterparts, other factors such as old age, congestive heart failure, smoking, $\beta$-blocker use, presence of bilateral lung infiltrates, elevated creatinine and severe vitamin D deficiency, appear to be more significant predictors of fatal outcome. Patients with acute metabolic dysfunctions, including hyperglycemia on admission are more likely to receive intensive care.
\end{abstract}

Keywords: Diabetes mellitus, Covid-19, Mortality, Saudi Arabia

*Correspondence: aalguwaihes@ksu.edu.sa

${ }^{1}$ Division of Endocrinology, Department of Internal Medicine, College of Medicine, King Saud University, Riyadh 11472, Saudi Arabia

Full list of author information is available at the end of the article

\section{Background}

The severe acute respiratory syndrome coronavirus 2 (SARS-CoV2) was first identified last December 2019 from a cluster of Wuhan residents initially diagnosed with pneumonia of unknown origin in Hubei, China

(c) The Author(s) 2020. This article is licensed under a Creative Commons Attribution 4.0 International License, which permits use, sharing, adaptation, distribution and reproduction in any medium or format, as long as you give appropriate credit to the original author(s) and the source, provide a link to the Creative Commons licence, and indicate if changes were made. The images or other third party material in this article are included in the article's Creative Commons licence, unless indicated otherwise in a credit line to the material. If material is not included in the article's Creative Commons licence and your intended use is not permitted by statutory regulation or exceeds the permitted use, you will need to obtain permission directly from the copyright holder. To view a copy of this licence, visit http://creativeco mmons.org/licenses/by/4.0/. The Creative Commons Public Domain Dedication waiver (http://creativecommons.org/publicdomain/ zero/1.0/) applies to the data made available in this article, unless otherwise stated in a credit line to the data. 
[1]. As the year 2020 progressed, this novel coronavirus strain became responsible for the catastrophic spread of coronavirus disease-19 (Covid-19), the pandemic which has so far claimed $\sim 1.3$ million human lives in more than 227 countries and territories as of November, 2020 [2]. Despite the alarming figures, Covid-19 has a fatality rate of $2.3 \%$, much lower than similar outbreaks such as SARS-CoV in 2003 (9.5\%) and the Middle East Respiratory Syndrome (MERS) CoV in 2012 (34.4\%) [3]. The Kingdom of Saudi Arabia (KSA), which is the largest sovereign state in the Arabian Peninsula in terms of geography and economy, was not only the epicenter of the MERS-CoV outbreak, it is also the most affected country with the highest mortality rate from Covid-19 in the Gulf Cooperation Council (GCC) region, and third highest number of confirmed cases in the Middle East after Iran and Iraq [2]. The kingdom's capital, Riyadh, has the highest number of SARS-CoV2 infected residents and citizens in the country [4].

In terms of predictors, preliminary evidence from 191 SARS-CoV2 infected patients in Wuhan showed that the most common factors associated with poor prognosis include advanced age, the presence of pre-existing conditions such as hypertension and diabetes mellitus (DM), as well as elevated inflammatory markers, amongst others [5]. These findings have been mostly consistent in other countries [6-8]. In KSA, the earliest national data (March, 2020) involving 1519 confirmed cases (mean age 36 years) also showed that the most common comorbidities were hypertension (8.8\%) and DM (7.6\%) [9]. This build-up of epidemiologic evidence made it increasingly clear that DM and other chronic, non-communicable diseases appear to negatively influence Covid-19 clinical outcomes [10, 11]. Furthermore, given the coronaviruses' affinity to angiotensin converting enzyme 2 (ACE2), concerns on the use of anti-hypertensive drugs such as angiotensin receptor blockers (ARBs), $\beta$-blockers, calcium channel blockers (CCBs) and ACE inhibitors have been raised, before being deemed safe and in some instances, protective against Covid-19 [12, 13]. ARB (valsartan) in particular, in combination with a neprilysin inhibitor (sacubitril), has been shown in patients to significantly reduce death from cardiovascular causes or first hospitalization for worsening heart failure and death from any cause [14]. Such treatment was more effective in reducing proteinuria, preserving renal ultrastructure and diminishing tubular injury, at least in animal models with early diabetic nephropathy [15].

As more cases have exponentially emerged over the past couple of months and given the novelty of the SARSCov2 pathogen, there is a need to update and increase the limited evidence on the ever-changing Covid-19 demographics, particularly in underrepresented regions such as the Middle East and KSA in particular, where chronic, non-communicable diseases such as DM are common [16]. Since most published evidence in this emerging field mostly came from the Far East and Western regions, data from other geographical areas representing other ethnicities, with different healthcare systems, may offer unique perspectives on this on-going pandemic. Indeed, while it has been already observed that DM and other chronic conditions increase morbidity and mortality from Covid19 [17], individuals from other ethnic minorities have been disproportionately affected [18]. To date, there is very limited evidence on the clinical characteristics and outcomes of hospitalized Covid-19 patients with or without DM in the Middle East and the GCC region in particular. The present study aims to fill this gap.

\section{Methodology}

Study design and setting-single-center, retrospective. KSUMC, Riyadh, KSA

Participants

Records of 439 adult Saudis and residents of Riyadh, KSA, who were confirmed positive for SARS-CoV2 and admitted at KSUMC-KKUH from May to July 2020, were included in this retrospective study. Children, pregnant women and those who tested negative for SARS-CoV2 were excluded. Diagnosis of SARS-CoV2 infection was based on the guidelines set by the Saudi Center for Disease Prevention and Control [19]. In brief, swab samples were obtained from the patient's upper respiratory tract (nasopharyngeal and/or oropharyngeal), placed in a sterile tube containing viral transport media and delivered immediately to a Biosafety Level 2-facility (BSL-2) with Biological Safety Cabinet Class II (BSC-II) in KSUMC, Riyadh, KSA, for reverse transcription-polymerase chain reaction (RT-PCR) analysis. Sample investigations were performed by certified laboratory personnel following manufacturer's recommendations for the defined cut-off cycle threshold (CT) value for each target gene. Waiver of informed consent approval was obtained from the Institutional Review Board (IRB) of the College of Medicine in King Saud University in Riyadh, Saudi Arabia (E-205090/July 5, 2020).

\section{Data collection}

Clinical information included demographics, symptoms and vital signs on arrival to ER, medical history and list of medications taken. Anthropometrics, serological tests done (complete blood count, profiles of liver, renal, thyroid, lipids, inflammatory markers and others) and chest $\mathrm{X}$-ray findings, if available, were obtained. Management given as well as the number of days from diagnosis to hospital admission, intensive care treatment, intubation and final outcome (discharged, died), were noted. 
For the purpose of this study, DM was defined as having one or more of the following criteria: known case of DM based on medical records, on anti-DM medications, $\mathrm{HbA} 1 \mathrm{c} \geq 6.5$ and fasting glucose $\geq 7.0 \mathrm{mmol} / \mathrm{l}$. NonDM was defined as having one or more of the following: no history of DM and/or anti-DM medication use, $\mathrm{HbA} 1 \mathrm{c}<6.5$ and fasting glucose $<7.0 \mathrm{mmol} / \mathrm{l}$. Normal ranges of all parameters were based on the cut-offs used in the central laboratory of KSUMC-KKUH where all analysis was done. A patient was considered 'severe' if he/ she required intensive care on admission.

\section{Data analysis}

Data analysis was done using SPSS version 21.0 (IBM, SPSS, Chicago, IL, USA) Demographic characteristics were presented as percentages (\%) and continuous variables were presented as mean \pm standard deviation (SD) for normal variables and mean \pm standard error mean (SEM) for non-normal variables. Chi Square test was done to determine differences in categorical variables. Independent T-test and Mann-Whitney U-test were done to determine differences between sex (adjusted for age and BMI) and DM status (adjusted for age, sex and BMI) for normal and non-normal variables, respectively. The same tests were applied to determine differences according to severity and final outcome, with Bonferroni adjusted p-values for multiple comparisons. Management and outcomes for all patients as well as significant predictors for each outcome were plotted as figures using MS Excel. Univariate and multivariate Cox-Regression analysis was used to determine unadjusted and adjusted hazard ratios (HR) with $95 \%$ confidence intervals (CI) for outcomes. To determine significant pre-existing conditions leading to outcomes of interest, all comorbidities were included in the model, including age, sex and BMI. All other parameters (medications and laboratory investigations) were adjusted for age, sex and BMI. Survival curve for DM was done using Kaplan-Meier and compared using log-rank test. Significance was set at $\mathrm{p}<0.05$.

\section{Results}

\section{Patient characteristics and comorbidities}

Table 1 shows the demographic and general characteristics of 439 Covid-19 patients admitted, stratified according to sex. The over-all median age was 55 years (minimum 19, maximum 101)]. Female patients were significantly older and had significantly higher BMI than males (p-values 0.03 and 0.001 , respectively). Male patients outnumber females 2:1. Saudis represented almost half of all admitted patients (49.7\%), with a higher proportion of males than females regardless of nationality $(\mathrm{p}<0001)$. Non-Saudi Arabs were the second most common demographic (22.8\%), followed by Indians (11.2\%).
Table 1 General characteristics of Covid-19 Patients

\begin{tabular}{|c|c|c|c|c|}
\hline $\begin{array}{l}\text { Parameters } \\
\mathrm{N}(\%)\end{array}$ & $\begin{array}{l}\text { All } \\
439(100)\end{array}$ & $\begin{array}{l}\text { Males } \\
300(68.3)\end{array}$ & $\begin{array}{l}\text { Females } \\
139(31.7)\end{array}$ & $p$-value \\
\hline $\begin{array}{l}\text { Age (years) } \\
\text { Median (min-max) }\end{array}$ & $55(19-101)$ & $54(19-87)$ & $59(20-101)$ & 0.03 \\
\hline $\mathrm{BMI}\left(\mathrm{kg} / \mathrm{m}^{2}\right)$ & $29.7 \pm 6.7$ & $28.8 \pm 5.8$ & $31.5 \pm 8.0$ & 0.001 \\
\hline \multicolumn{5}{|l|}{ Nationality (\%) } \\
\hline Saudi & $218(49.7)$ & $123(41.0)$ & $95(68.3)$ & $<0.001$ \\
\hline Arab (non-Saudi) & $100(22.8)$ & $73(24.3)$ & $27(19.4)$ & \\
\hline Filipino & $20(4.6)$ & $16(5.3)$ & $4(2.9)$ & \\
\hline Bangladeshi & $15(3.4)$ & $15(5.0)$ & 0 & \\
\hline Pakistani & $12(2.7)$ & $10(3.3)$ & $2(1.4)$ & \\
\hline Indian & $49(11.2)$ & $47(15.7)$ & $2(1.4)$ & \\
\hline Afghani & $4(0.9)$ & $3(1.0)$ & $1(0.7)$ & \\
\hline Others & $21(4.8)$ & $12(4.3)$ & $8(5.8)$ & \\
\hline \multicolumn{5}{|l|}{ Comorbidities (\%) } \\
\hline Obesity & $178(42.2)$ & $101(35.3)$ & $77(56.6)$ & $<0.001$ \\
\hline Hypertension & $187(42.6)$ & $109(36.3)$ & $78(56.1)$ & $<0.001$ \\
\hline Diabetes mellitus* & $300(68.3)$ & $200(66.7)$ & $100(71.9)$ & NS \\
\hline $\begin{array}{l}\text { Cardiovascular } \\
\text { disease }\end{array}$ & $44(10.0)$ & $31(10.3)$ & $13(9.4)$ & NS \\
\hline $\begin{array}{l}\text { Congestive heart } \\
\text { failure }\end{array}$ & $18(4.1)$ & $12(4.0)$ & $6(4.3)$ & NS \\
\hline $\begin{array}{l}\text { Chronic kidney } \\
\text { disease }\end{array}$ & $22(5.0)$ & $13(4.3)$ & $9(6.5)$ & NS \\
\hline Stroke & $17(3.9)$ & $10(3.3)$ & $7(5.0)$ & NS \\
\hline Smoking & $9(2.6)$ & $7(3.2)$ & $2(1.6)$ & 0.05 \\
\hline $\begin{array}{l}\text { Vitamin D defi- } \\
\text { ciency }^{* *}\end{array}$ & $112(74.7)$ & $75(75.8)$ & $37(72.5)$ & NS \\
\hline \multicolumn{5}{|l|}{ Medications (\%) } \\
\hline$\beta$-Blockers & 73 (16.6) & $50(16.7)$ & $23(16.9)$ & NS \\
\hline ACE inhibitors & $48(10.9)$ & $33(11.0)$ & $15(10.8)$ & NS \\
\hline ARB & $63(14.4)$ & $31(10.3)$ & $32(23.5)$ & $<0.001$ \\
\hline $\mathrm{CCB}$ & $95(21.8)$ & $55(18.3)$ & $40(29.4)$ & 0.03 \\
\hline Statins & $111(25.5)$ & $69(23.1)$ & $42(30.9)$ & NS \\
\hline GLP-1 agonists & $5(1.1)$ & $3(1.0)$ & $2(1.5)$ & NS \\
\hline Insulin & $63(14.4)$ & $28(9.4)$ & $35(25.7)$ & $<0.001$ \\
\hline Oral hypoglycemic & $148(33.7)$ & $89(29.8)$ & $59(43.4)$ & 0.006 \\
\hline Anti-coagulants & $19(4.3)$ & $9(3.0)$ & $10(7.4)$ & 0.04 \\
\hline Anti-platelets & $80(18.2)$ & $51(17.0)$ & $29(21.3)$ & NS \\
\hline Levothyroxine & $25(5.7)$ & $9(3.0)$ & $16(11.6)$ & 0.001 \\
\hline
\end{tabular}

*DM cases were known + newly diagnosed; ${ }^{* *}$ Only 150 cases had vitamin D status; significant at $\mathrm{p}<0.05$

Three-fourths of all admitted patients whose vitamin D status were assessed had vitamin D deficiency $(25(\mathrm{OH})$ $\mathrm{D}<50 \mathrm{nmol} / \mathrm{l}$ ) (74.7\%). Other common comorbidities noted were hypertension (42.6\%) and obesity (42.2\%), all of which more prevalent in female than male patients (p-values 0.001 and $<0.001$, respectively). The prevalence of DM was $68.3 \%$ based on known records + newly diagnosed cases as defined previously. Smoking was the least 
common risk factor with only $2.6 \%$ and were mostly male patients $(p=0.05)$. Among the maintenance medications noted, oral hypoglycemic drugs were the most common (33.7\%), followed by statins (25.5\%), CCBs (21.8\%), antiplatelets (18.2\%) and $\beta$-Blockers (16.6\%). With the exception of ACE inhibitors, female patients had a significantly higher percentage of maintenance medication use than males, including ARBs, CCBs, insulin, oral hypoglycemic and levothyroxine (p-values $<0.001,0.03,<0.001$, $0.006,0.04$ and 0.001 , respectively). None of the admitted patients had COPD.

\section{Symptoms on admission}

Table 2 shows the presenting symptoms and vital signs of all patients on admission. Majority had fever (75.2\%), dyspnea (72.8\%) and cough (70.0\%) on presentation. One out of every 5 patients also had nausea/vomiting (23.1\%) and/or diarrhea (21.3\%). A small percentage of patients reported anosmia (4.6\%), ageusia (5.3\%) and myalgia (9.5\%). Stratified according to sex, male patients had a significantly higher prevalence of fever and diarrhea than females (p-values 0.01 and 0.04, respectively). Among the vital signs assessed, tachypnea and hypoxemia were observed, as indicated by the over-all mean respiratory rate $\left(25.4 \pm 8.9\right.$ breaths per minute) and $\mathrm{SpO}_{2}(91.0 \pm 8.7)$. Respiratory rate was worse in males than females, after adjusting for age and BMI $(\mathrm{p}=0.01)$.

When stratified according to DM status, DM patients had a significantly higher prevalence of cough and dyspnea than non-DM patients ( $\mathrm{p}$-values 0.02 and $<0.001$, respectively). In terms of vital signs, tachypnea was significantly worse in DM than non-DM patients, after adjusting for age, sex and BMI (p-value 0.009). Systolic blood pressure was also significantly higher in DM than non-DM patients $(\mathrm{p}=0.018)$. The rest of the parameters are shown in Table 2.

No differences in symptoms were observed among severe $(\mathrm{N}=123)$ and non-severe $(\mathrm{N}=316)$ patients, as well as those who died $(\mathrm{N}=77)$ versus those discharged $(\mathrm{N}=343)$. Concerning vital signs, a significantly lower respiratory rate and $\mathrm{SpO}_{2}$ were noted among severe than non-severe cases ( $\mathrm{p}$-values $<0.01)$. Patients who died also had a significantly lower $\mathrm{SpO}_{2}$ as well diastolic blood pressure, with a significantly higher respiratory rate on admission than patients who were discharged ( $\mathrm{p}$-values $<0.01$ ) (Additional file 1).

\section{Radiologic and serologic characteristics}

Table 3 shows the clinical characteristics of Covid-19 patients based on chest X-ray and laboratory investigations. Majority of patients $(60 \%)$ showed bilateral lung infiltrates and only $10 \%$ showed none. Altered levels of metabolic and inflammatory profiles were observed in almost all serologic tests conducted. Age- and BMIadjusted differences revealed that male patients had significantly higher hemoglobin and neutrophil counts than females ( $\mathrm{p}$-values $<0.001$ and 0.04 , respectively), while females had a significantly higher platelet count than males $(\mathrm{p}=0.04)$. In the liver profile, male patients also had a significantly higher circulating levels LDH

Table 2 Presenting symptoms and vital signs of Covid-19 patients on admission

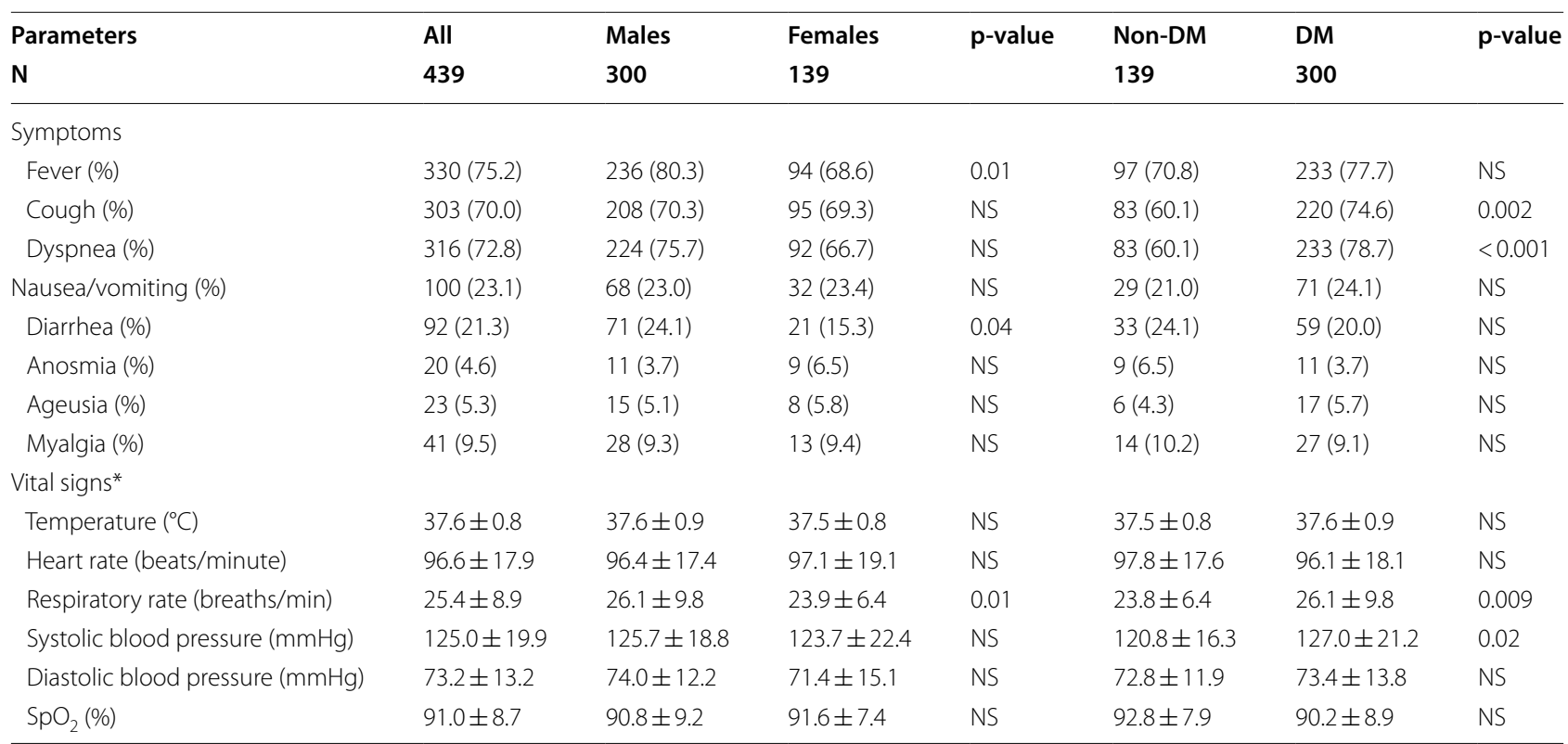

*Denotes $\mathrm{p}$-values adjusted for age and BMI in males and females; age, sex and BMI in non-DM and DM; significant at $\mathrm{p}<0.05$ 
Table 3 Clinical characteristics of Covid-19 patients on admission

\begin{tabular}{|c|c|c|c|c|c|c|c|}
\hline Parameters & All & Males & Females & p-value* & Non-DM & DM & $p$-value ${ }^{* *}$ \\
\hline $\mathbf{N}$ & 439 & 300 & 139 & & 139 & 300 & \\
\hline $\begin{array}{l}\text { Chest X-ray } \\
\text { No infiltrates }\end{array}$ & $131(30.4)$ & $94(31.8)$ & $37(27.4)$ & NS & $61(43.9)$ & $70(23.5)$ & $<0.001$ \\
\hline Unilateral infiltrates & $43(10.0)$ & $31(10.5)$ & $12(8.9)$ & & $7(5.3)$ & $36(12.1)$ & \\
\hline Bilateral infiltrates & $257(59.6)$ & $171(57.8)$ & $86(61.9)$ & & $65(48.9)$ & $192(64.4)$ & \\
\hline \multicolumn{8}{|l|}{ Complete blood count } \\
\hline Hemoglobin (g/l) (120-160) & $130 \pm 1.2$ & $134.6 \pm 1.4$ & $120.4 \pm 1.7$ & $<0.001$ & $131.2 \pm 2.2$ & $129.6 \pm 1.3$ & NS \\
\hline WBC count (4.0-11.0) & $8.0 \pm 0.2$ & $8.3 \pm 0.3$ & $7.3 \pm 0.3$ & NS & $8.0 \pm 0.4$ & $8.0 \pm 0.3$ & NS \\
\hline Platelet count (140-450) & $249.7 \pm 4.7$ & $244.7 \pm 5.7$ & $260.5 \pm 8.3$ & 0.04 & $249.6 \pm 8.4$ & $249.7 \pm 5.7$ & NS \\
\hline Lymphocyte (1-5) & $1.3 \pm 0.1$ & $1.2 \pm 0.1$ & $1.4 \pm 0.1$ & NS & $1.5 \pm 0.2$ & $1.2 \pm 0.1$ & NS \\
\hline Neutrophils (2.0-7.5) & $6.0 \pm 0.2$ & $6.4 \pm 0.3$ & $5.3 \pm 0.3$ & 0.04 & $5.8 \pm 0.3$ & $6.1 \pm 0.3$ & NS \\
\hline D-dimer ( $\mu \mathrm{g} / \mathrm{ml})(0.22-0.45)$ & $2.2 \pm 0.2$ & $2.3 \pm 0.2$ & $2.0 \pm 0.2$ & NS & $1.7 \pm 0.2$ & $2.4 \pm 0.2$ & NS \\
\hline \multicolumn{8}{|l|}{ Liver profile } \\
\hline ALT (U/I) (20-65) & $57.6 \pm 3.1$ & $62.3 \pm 3.2$ & $47.1 \pm 7.1$ & NS & $64.7 \pm 5.8$ & $54.4 \pm 3.7$ & NS \\
\hline AST (U/I) (15-37) & $60.8 \pm 3.1$ & $62.5 \pm 2.9$ & $57.0 \pm 7.4$ & NS & $68.1 \pm 6.9$ & $57.6 \pm 3.2$ & NS \\
\hline LDH (U/I) (84-246) & $455.2 \pm 11.9$ & $475.3 \pm 14.7$ & $409.0 \pm 19.5$ & 0.003 & $440.2 \pm 26.4$ & $461.7 \pm 12.7$ & NS \\
\hline \multicolumn{8}{|l|}{ Renal Profile } \\
\hline BUN (mmol/l) (2.5-6.4) & $7.7 \pm 0.4$ & $7.8 \pm 0.5$ & $7.4 \pm 0.6$ & NS & $6.6 \pm 0.7$ & $8.2 \pm 0.5$ & NS \\
\hline Creatinine $(\mu \mathrm{mol} / \mathrm{l})(49-90)$ & $123.6 \pm 8.0$ & $129.6 \pm 9.8$ & $110.6 \pm 13.8$ & NS & $110.4 \pm 12.3$ & $129.7 \pm 10.2$ & NS \\
\hline $\mathrm{Na}(\mathrm{mmol} / \mathrm{l})(136-145)$ & $136.8 \pm 0.3$ & $137.0 \pm 0.3$ & $136.3 \pm 0.5$ & NS & $137.8 \pm 0.5$ & $136.4 \pm 0.3$ & NS \\
\hline $\mathrm{K}(\mathrm{mmol} / \mathrm{l})(3.5-5.1)$ & $4.4 \pm 0.1$ & $4.4 \pm 0.05$ & $4.6 \pm 0.3$ & NS & $4.2 \pm 0.1$ & $4.6 \pm 0.1$ & NS \\
\hline \multicolumn{8}{|l|}{ Lipid profile } \\
\hline Triglycerides (mmol/l) & $2.0 \pm 0.09$ & $2.1 \pm 0.1$ & $1.9 \pm 0.1$ & NS & $1.6 \pm 0.1$ & $2.1 \pm 0.1$ & 0.03 \\
\hline HDL-Cholesterol (mmol/l) & $0.88 \pm 0.05$ & $0.8 \pm 0.1$ & $0.9 \pm 0.05$ & NS & $0.8 \pm 0.05$ & $0.9 \pm 0.06$ & NS \\
\hline LDL-Cholesterol (mmol/l) & $2.0 \pm 0.08$ & $2.0 \pm 0.1$ & $2.0 \pm 0.1$ & NS & $2.0 \pm 0.2$ & $2.0 \pm 0.09$ & NS \\
\hline \multicolumn{8}{|l|}{ Inflammatory markers } \\
\hline Ferritin ( $\mu \mathrm{g} / \mathrm{ml})(13-150)$ & $942.6 \pm 54.6$ & $1116.3 \pm 72.7$ & $570.7 \pm 60.9$ & $<0.001$ & $859.2 \pm 90.5$ & $980.7 \pm 67.9$ & 0.049 \\
\hline Procalcitonin (ng/ml) (0-0.046) & $2.6 \pm 0.6$ & $2.0 \pm 0.6$ & $3.9 \pm 1.5$ & NS & $4.2 \pm 1.8$ & $2.0 \pm 0.6$ & NS \\
\hline $\operatorname{ESR}(\mathrm{mm} / \mathrm{h})(0-24)$ & $70.5 \pm 2.0$ & $67.5 \pm 2.3$ & $77.2 \pm 3.6$ & NS & $63.1 \pm 3.8$ & $74.0 \pm 2.2$ & NS \\
\hline $\operatorname{CRP}(\mathrm{mg} / \mathrm{l})(<10.0)$ & $104.8 \pm 3.8$ & $110.6 \pm 4.8$ & $91.2 \pm 5.7$ & 0.003 & $97.3 \pm 7.3$ & $107.9 \pm 4.4$ & NS \\
\hline IL-6 (pg/ml) (1.5-7.0) & $172.6 \pm 28.3$ & $183.5 \pm 37.2$ & $145.4 \pm 34.7$ & NS & $143.5 \pm 42.3$ & $183.7 \pm 35.6$ & NS \\
\hline \multicolumn{8}{|l|}{ Thyroid profile } \\
\hline $\mathrm{TSH}(\mu \mathrm{IU} / \mathrm{ml})(0.25-5.0)$ & $2.1 \pm 0.5$ & $2.1 \pm 0.7$ & $2.1 \pm 0.5$ & NS & $1.7 \pm 0.2$ & $2.2 \pm 0.7$ & NS \\
\hline FT4 (pmol/l) (10-24.5) & $16.4 \pm 0.3$ & $16.4 \pm 0.3$ & $16.5 \pm 0.6$ & NS & $15.6 \pm 0.5$ & $16.8 \pm 0.4$ & 0.02 \\
\hline \multicolumn{8}{|l|}{ Glycemic profile } \\
\hline $\operatorname{HbA1c}(\%)$ & $8.0 \pm 0.1$ & $7.9 \pm 0.2$ & $8.1 \pm 0.2$ & NS & $5.5 \pm 0.1$ & $10.6 \pm 0.3$ & $<0.001$ \\
\hline Fasting Glucose (mmol/l) & $9.2 \pm 0.3$ & $9.1 \pm 0.3$ & $9.6 \pm 0.5$ & NS & $5.8 \pm 0.05$ & $8.6 \pm 0.1$ & $<0.001$ \\
\hline \multicolumn{8}{|l|}{ Other markers } \\
\hline Corrected Ca (mmol/l) (2.1-2.55) & $2.3 \pm 0.01$ & $2.31 \pm 0.01$ & $2.34 \pm 0.01$ & 0.02 & $2.3 \pm 0.01$ & $2.3 \pm 0.01$ & NS \\
\hline $25(\mathrm{OH}) \mathrm{D}(\mathrm{nmol} / \mathrm{l})(75-250)$ & $40.4 \pm 2.4$ & $39.0 \pm 2.8$ & $43.1 \pm 4.4$ & NS & $38.1 \pm 6.2$ & $41.1 \pm 2.5$ & NS \\
\hline
\end{tabular}

*Denotes $\mathrm{p}$-values adjusted for age and BMl; ${ }^{* *}$ denotes $\mathrm{p}$-values adjusted for age, sex and BMl; significant at $\mathrm{p}<0.05$

than females $(\mathrm{p}=0.003)$. No differences were observed between sexes with respect to renal profile. Nonetheless, mean circulating BUN and creatinine levels were above normal. Lipid and thyroid profiles were unremarkable. On the other hand, inflammatory markers were markedly elevated in all patients, with males having significantly higher levels of ferritin and CRP (p-values $<0.001$ and 0.003 ) than females. Mean corrected calcium levels were within normal range, but females had significantly higher levels than males $(\mathrm{p}=0.02)$. In all patients, only 150 had records for $25(\mathrm{OH}) \mathrm{D}$ levels, majority of whom $(74.7 \%)$ were well below the deficiency range (not shown in table). Seven patients had severe vitamin D deficiency $(<12.5 \mathrm{nmol} / \mathrm{l})$ 
(not shown in table). The rest of the parameters were shown in Table 3.

When stratified according to DM status, age-, sex- and BMI-adjusted comparisons revealed higher prevalence of bilateral lung infiltrates in DM as compared to non-DM patients $(\mathrm{p}<0.001)$. No significant differences observed in most serologic parameters with the exception of triglycerides, ferritin and FT4, all of which were significantly higher in DM than non-DM patients (p-values 0.03, $0.049,0.014$ and 0.02 , respectively) (Table 3 ).

When grouped according to severity status, the presence of bilateral lung infiltrates, mean D-dimer, AST, $\mathrm{LDH}$, ferritin and CRP were all significantly higher among severe than non-severe patients (adjusted p-values $<0.01)$. Lastly, when measured parameters were compared according to final outcome, patients who died had a significantly higher prevalence of bilateral lung infiltrates as well as significantly higher circulating levels of hemoglobin, neutrophils, D-dimer, BUN, creatinine, potassium, triglycerides, ferritin and CRP on admission, than patients who were discharged (adjusted p-values < 0.01) (Additional file 2).

\section{Management and outcomes}

Figure 1 shows that more than $80 \%$ of all admitted patients were transferred to ward, while 79 patients (18.0\%) needed immediate intensive care. Among the supportive medications provided, antibiotics was the most common (88.6\%) and hydroxychloroquine the least $(1.8 \%)$. During the course of admission, 77 patients $(17.5 \%)$ required intubation and an additional 123 patients were eventually transferred to ICU. Overall mortality rate was $17.5 \%$ and $80.3 \%$ were considered recovered and discharged. Median number of days from diagnosis to ICU admission was 3, from diagnosis to discharge was 10 days and from diagnosis to death was 13 days (Fig. 1). No significant differences were seen in the management and outcomes when stratified according to sex, with the exception of antibiotic use, being modestly more prevalent in males than females $(p=0.05)$ (Table 4).

With regards to DM status, a significantly higher proportion of DM patients received oxygen on arrival to ER $(\mathrm{p}=0.006)$ and were more commonly treated with antibiotics and dexamethasone ( $\mathrm{p}$-values $<0.001$ and $<0.001$, respectively) than non-DM patients. DM patients were also more likely to be intubated than non-DM patients $(p=0.04)$. Mortality rate in the DM group was significantly higher than the non-DM group (20.5\% versus $12.3 \% ; \mathrm{p}=0.04)$. Furthermore, Kaplan-Meier survival analysis curve showed that DM patients had a significantly shorter survival time than non-DM patients $(\mathrm{p}=0.016)$ (Fig. 2). No differences were observed in terms of duration from diagnosis to admission, intubation, ICU admission, discharge and mortality. The rest of the outcomes were mentioned in Table 4.

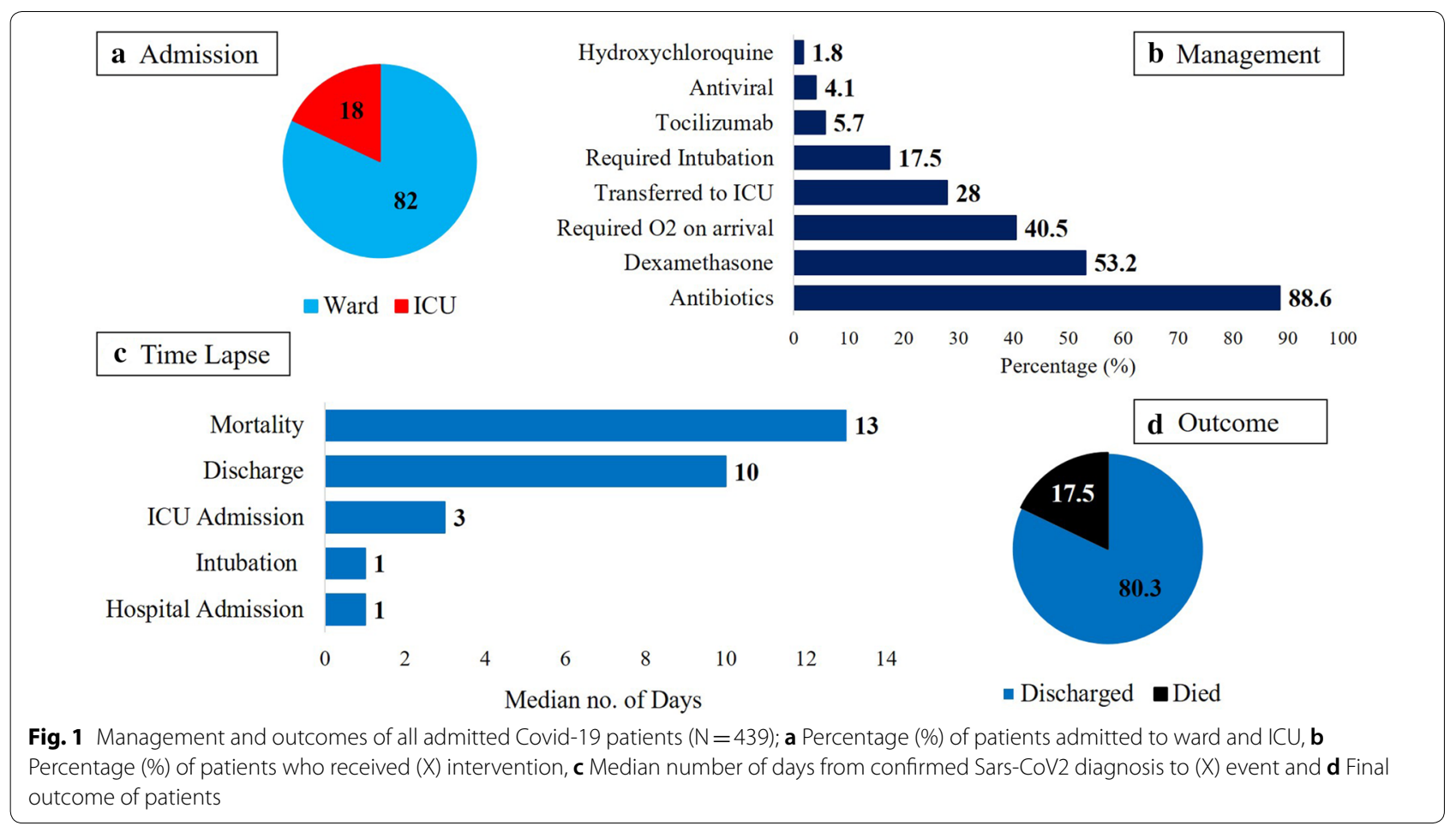


Table 4 Management and outcomes of Covid-19 patients according to sex and DM status

\begin{tabular}{|c|c|c|c|c|c|c|}
\hline Parameters (\%) & Males & Females & p-value & Non-DM & DM & $p$-value \\
\hline $\mathrm{N}$ & 300 & 139 & & 139 & 300 & \\
\hline On admission & & & NS & & & NS \\
\hline Ward & $242(80.7)$ & $118(84.9)$ & & $118(84.9)$ & $242(80.7)$ & \\
\hline ICU & $58(19.3)$ & $21(15.1)$ & & $21(15.1)$ & $58(19.3)$ & \\
\hline Required $\mathrm{O}_{2}$ on arrival to $\mathrm{ER}$ & $124(41.3)$ & $54(38.8)$ & NS & $43(30.9)$ & $135(45.0)$ & 0.006 \\
\hline Antiviral & $10(3.3)$ & $8(5.8)$ & NS & $9(6.5)$ & $9(3.0)$ & NS \\
\hline Tocilizumab & $19(6.3)$ & $6(4.3)$ & NS & $4(2.9)$ & $21(7.0)$ & NS \\
\hline Hydroxychloroquine & $4(1.3)$ & $4(2.9)$ & NS & $5(3.6)$ & $3(1.0)$ & NS \\
\hline Antibiotics & $272(90.7)$ & $117(84.2)$ & 0.05 & $106(76.3)$ & $283(94.3)$ & $<0.001$ \\
\hline Dexamethasone & $164(54.7)$ & $69(50.0)$ & NS & $50(36.2)$ & $183(61.0)$ & $<0.001$ \\
\hline Required Intubation & $54(18.2)$ & $23(16.5)$ & NS & $17(12.3)$ & $60(20.3)$ & 0.04 \\
\hline Transferred to ICU & $82(27.3)$ & $41(29.7)$ & NS & $32(23.4)$ & $91(30.5)$ & NS \\
\hline \multicolumn{7}{|l|}{ Outcome } \\
\hline Mortality & $55(18.6)$ & $22(16.3)$ & NS & $17(12.3)$ & $60(20.5)$ & 0.04 \\
\hline Discharged/Recovered & $234(79.9)$ & $109(81.3)$ & NS & $118(86.1)$ & $225(77.6)$ & NS \\
\hline \multicolumn{7}{|c|}{ Time lapse from diagnosis [median number of days (min-max)] } \\
\hline Admission & $1(1-37)$ & $1(1-32)$ & NS & $1(1-19)$ & $1(1-37)$ & NS \\
\hline Intubation & $1(1-23)$ & $1(1-19)$ & NS & $1(1-20)$ & $1(1-23)$ & NS \\
\hline ICU admission & $2(1-20)$ & $3(1-16)$ & NS & $3.0(1-16)$ & $3(1-20)$ & NS \\
\hline Discharge & $10(1-50)$ & $11(1-50)$ & NS & $10(2-50)$ & $10(1-50)$ & NS \\
\hline Mortality & $13.5(1-47)$ & $11(1-29)$ & NS & $15(1-28)$ & $12(1-47)$ & NS \\
\hline
\end{tabular}

Significant at $\mathrm{p}<0.05$

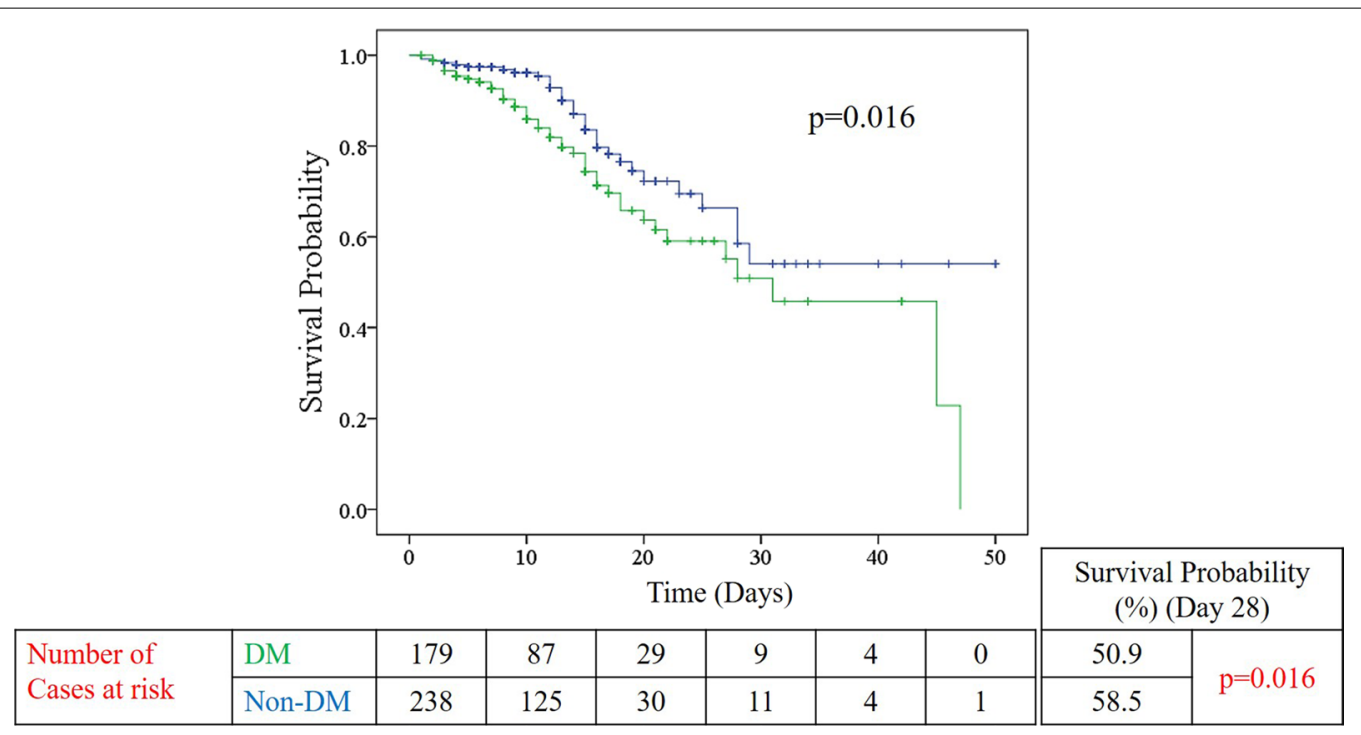

Fig. 2 Kaplan-Meier survival analysis according to DM status (DM-green; non-DM-blue). p-value obtained from Log Rank Mantel-Cox test

A sub-analysis was done to determine differences in mortality rates among Covid-19 patients whose HbA1c levels were measured: non-DM (Hba1c $<5.7$; $\mathrm{N}=25$ ), prediabetes (HbA1c 5.7-6.4; $\mathrm{N}=72$ ) and $\mathrm{DM}(\mathrm{HbA1c} \geq 6.5 ; \mathrm{N}=227)$. Death rates for non-DM, prediabetes and DM were $8.0 \%, 14.7 \%$ and $15.5 \%$ $(\mathrm{p}=0.58)$. There was no difference in the prevalence of DM $(70.6 \%$ versus $66.1 \%)$ and death rates $(18.6 \%$ versus 17.3\%) between Saudis and non-Saudis (not shown in tables). 
Significant risk factors for outcomes of interest

Multivariate cox proportional hazards regression model revealed that age [HR 3.0 (CI 1.7-5.3); $\mathrm{p}<0.001$ ], congestive heart failure [adjusted HR 3.5 (CI 1.4-8.3); $\mathrm{p}=0.006$ ], smoking [adjusted HR 5.8 (CI 2.0-17.2); $\mathrm{p}<0.001$ ], $\beta$-blocker use [adjusted HR 1.7 (CI 1.0-2.9); $\mathrm{p}=0.04$ ], bilateral lung infiltrates [adjusted HR 1.9 (CI $1.1-3.3) ; \mathrm{p}=0.02$ ], creatinine $>90 \mu \mathrm{mol} / \mathrm{l}$ [adjusted HR 2.1 (CI 1.3-3.5); $\mathrm{p}=0.004$ ] and severe vitamin $\mathrm{D}$ deficiency [adjusted HR 7.0 (CI 1.7-28.2); $\mathrm{p}=0.007$ ] were significant risk factors associated with death among hospitalized Covid-19 patients (Table 5). On the other hand, smoking [adjusted HR 5.2 (CI 1.8-14.8); $\mathrm{p}=0.002$ ], $\beta$-blocker use [adjusted HR 1.7 (CI 1.1-2.8); $\mathrm{p}=0.02$ ], $\mathrm{RBG} \geq 11.1 \mathrm{mmol} / \mathrm{l}$ [adjusted HR 1.5 (CI 1.0-2.2); $\mathrm{p}=0.04$ ], neutrophil count $>7.5$ [adjusted HR 1.6 (CI 1.1-2.4); $\mathrm{p}=0.02$ ], creatinine $>90 \mu \mathrm{mol} / \mathrm{l}$ [adjusted HR 1.8 (CI 1.2-2.2); $\mathrm{p}=0.006$ ] and ALT $>65 \mathrm{U} / \mathrm{l}$ [adjusted HR 1.6 (CI 1.1-2.4); $\mathrm{p}=0.02$ ] were significantly associated with ICU admission. Lastly, the significant risk factors for intubation were congestive heart failure [adjusted HR
2.8 (CI 1.0-7.6); $\mathrm{p}=0.048$ ], smoking [adjusted HR 7.1 (CI 2.4-20.9); $\mathrm{p}<0.001$ ] and creatinine $>90 \mu \mathrm{mol} / \mathrm{l}$ [adjusted HR 2.1 (CI 1.3-3.6); $\mathrm{p}=0.003$ ] (Table 5). Unadjusted HRs with $95 \%$ CIs for the parameters mentioned, including inflammatory markers are provided as a Additional file 3. The top predictors for each outcome have been plotted in Fig. 3.

\section{Discussion}

Data from hospitalized Covid-19 patients with outcomes in the Middle East and the Gulf Cooperation Council (GCC) countries in particular, are relatively scarce. To the best of our knowledge, this retrospective study is one of the few, if not the first study to comprehensively present the clinical characteristics and outcomes of Covid19 patients with and without DM admitted at a tertiary hospital in KSA.

\section{Main findings}

Hospitalized Covid-19 patients with DM outnumber those without by $2: 1$. Death rate was also significantly

Table 5 Factors for outcomes of interest using the multivariate Cox proportional hazards regression model

\begin{tabular}{|c|c|c|c|c|c|c|c|c|c|}
\hline \multirow[t]{3}{*}{ Risk factor } & \multicolumn{9}{|c|}{ Outcomes } \\
\hline & \multicolumn{3}{|c|}{ Mortality } & \multicolumn{3}{|c|}{ ICU admission } & \multicolumn{3}{|c|}{ Intubation } \\
\hline & HR & $95 \% \mathrm{Cl}$ & p-value & HR & $95 \% \mathrm{Cl}$ & p-value & HR & $95 \% \mathrm{Cl}$ & p-value \\
\hline Age $>55$ years & 3.0 & $1.7-5.3$ & $<0.001$ & 1.1 & $0.7-1.7$ & 0.62 & 1.4 & $0.9-2.4$ & 0.14 \\
\hline Male & 1.4 & $0.9-2.4$ & 0.17 & 1.2 & $0.8-1.8$ & 0.44 & 1.4 & $0.8-2.4$ & 0.22 \\
\hline \multicolumn{10}{|l|}{ Comorbidities } \\
\hline Obesity & 1.0 & $0.6-1.6$ & 0.93 & 1.2 & $0.8-1.7$ & 0.47 & 1.1 & $0.7-1.8$ & 0.73 \\
\hline Hypertension & 0.8 & $0.4-1.6$ & 0.55 & 1.0 & $0.5-1.9$ & 0.97 & 1.0 & $0.5-2.1$ & 0.92 \\
\hline Diabetes mellitus & 1.2 & $0.7-2.3$ & 0.49 & 1.0 & $0.6-1.7$ & 0.96 & 1.2 & $0.6-2.2$ & 0.60 \\
\hline Cardiovascular disease & 1.8 & $0.7-4.4$ & 0.23 & 1.2 & $0.5-3.1$ & 0.64 & 1.0 & $0.3-3.0$ & 0.96 \\
\hline Chronic kidney disease & 0.7 & $0.2-2.0$ & 0.49 & 1.0 & $0.4-2.5$ & 0.95 & 0.7 & $0.2-2.5$ & 0.61 \\
\hline Congestive heart failure & 3.5 & $1.4-8.3$ & 0.006 & 1.9 & $0.7-5.1$ & 0.19 & 2.8 & $1.0-7.6$ & 0.048 \\
\hline Stroke & 1.3 & $0.5-3.8$ & 0.61 & 1.0 & $0.4-3.0$ & 0.95 & 1.9 & $0.7-5.2$ & 0.20 \\
\hline Smoking & 5.8 & $2.0-17.2$ & 0.002 & 5.2 & $1.8-14.8$ & 0.002 & 7.1 & $2.4-20.9$ & $<0.001$ \\
\hline \multicolumn{10}{|l|}{ Medications } \\
\hline$\beta$-Blocker use & 1.7 & $1.0-2.9$ & 0.04 & 1.7 & $1.1-2.8$ & 0.02 & 1.6 & $0.9-2.8$ & 0.11 \\
\hline ACE inhibitor use & 0.7 & $0.3-1.4$ & 0.29 & 1.0 & $0.6-1.8$ & 0.86 & 0.9 & $0.4-1.7$ & 0.66 \\
\hline ARB Use & 1.3 & $0.6-2.6$ & 0.46 & 1.7 & $0.8-3.5$ & 0.14 & 1.4 & $0.6-3.3$ & 0.38 \\
\hline \multicolumn{10}{|l|}{ Laboratory investigations } \\
\hline $\mathrm{RBG}(\geq 11.1 \mathrm{mmol} / \mathrm{l})$ & 1.2 & $0.7-1.9$ & 0.54 & 1.5 & $1.0-2.2$ & 0.04 & 1.6 & $1.0-2.5$ & 0.07 \\
\hline $\mathrm{FPG}(\geq 7.0 \mathrm{mmol} / \mathrm{l})$ & 1.2 & $0.7-2.2$ & 0.53 & 1.0 & $0.6-1.6$ & 0.90 & 1.1 & $0.6-1.9$ & 0.81 \\
\hline $\mathrm{HbA} 1 \mathrm{c}>9.0 \%$ & 0.7 & $0.3-1.3$ & 0.25 & 1.0 & $0.6-1.6$ & 0.98 & 0.9 & $0.5-1.8$ & 0.85 \\
\hline Bilateral lung infiltrates & 1.9 & $1.1-3.3$ & 0.02 & 1.4 & $0.9-2.1$ & 0.14 & 2.0 & $1.1-3.4$ & 0.017 \\
\hline Neutrophil count > 7.5 & 1.4 & $0.9-2.2$ & 0.19 & 1.6 & $1.1-2.4$ & 0.02 & 1.5 & $0.9-2.5$ & 0.09 \\
\hline Creatinine $>90 \mu \mathrm{mol} / /$ & 2.1 & $1.3-3.5$ & 0.004 & 1.8 & $1.2-2.8$ & 0.006 & 2.1 & $1.3-3.6$ & 0.003 \\
\hline $\mathrm{ALT}>65 \mathrm{U} / \mathrm{l}$ & 1.3 & $0.8-2.1$ & 0.35 & 1.6 & $1.1-2.4$ & 0.02 & 1.4 & $0.9-2.4$ & 0.17 \\
\hline $25(\mathrm{OH}) \mathrm{D}<12.5 \mathrm{nmol} / /$ & 7.0 & $1.7-28.2$ & 0.007 & 3.0 & $0.7-13.4$ & 0.16 & 2.0 & $0.4-10.1$ & 0.39 \\
\hline
\end{tabular}




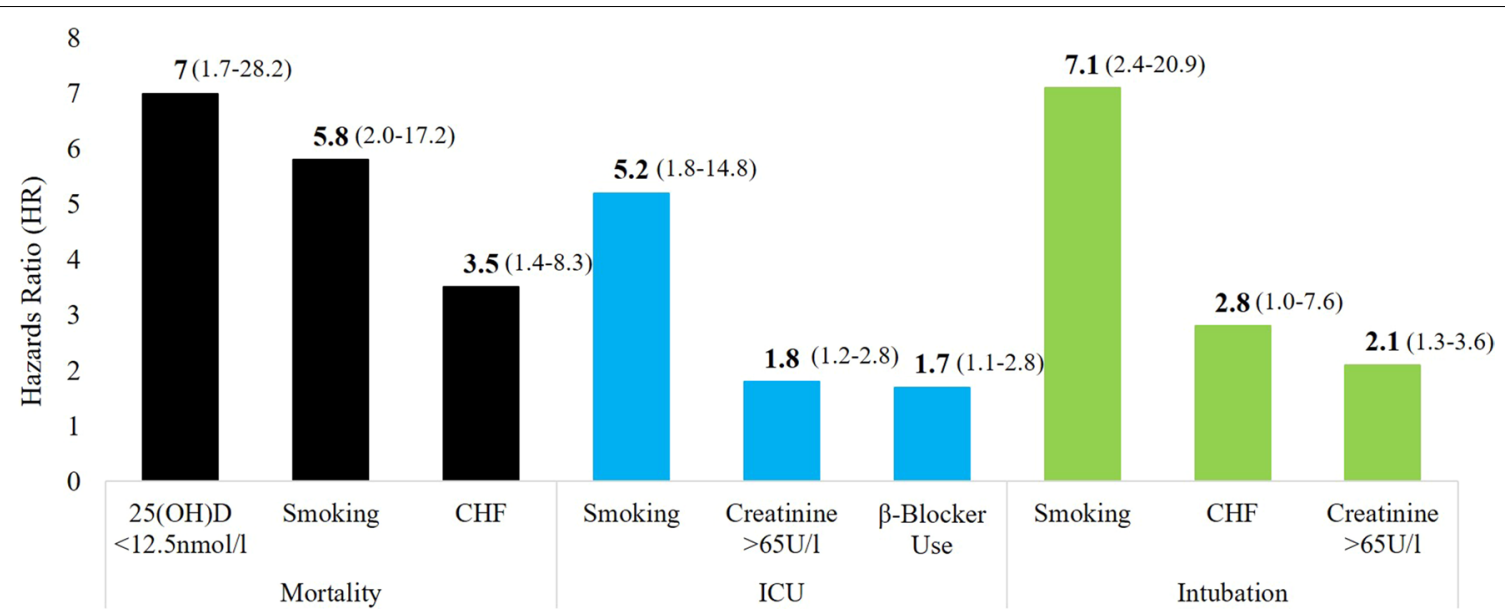

Fig. 3 Top significant predictors (adjusted for covariates) [HR (95\% CI)] for selected outcomes: mortality (black), ICU (blue) and intubation (green)

higher in the DM than non-DM group, with DM patients generally having worse clinical symptoms and metabolic profile than their non-DM counterparts. These findings largely support previous observations from pooled analyses associating DM Covid-19 severity and outcomes [20, $21]$. However, it is noteworthy that DM was not associated with mortality after adjustments for age, sex, BMI, and other pre-existing conditions. Levels of HbA1c, fasting and random glucose on admission were also not associated with mortality after adjusting for covariates. This indicates that DM alone may not fully explain the adverse outcomes associated with Covid-19. Similarly, data from a large scale, multi-center, retrospective study in Wuhan involving 1561 Covid-19 patients described the presence of DM as not independently associated with in-hospital deaths [22]. A more recent evidence in the US involving 463 Covid-19 also support the lack of association between DM and mortality, as well as risk for ICU admission and mechanical ventilation [23]. In contrast, preliminary data in UK indicated that an overwhelming one-third of Covid-19 patients dying in hospitals had DM [24]. The absence of significant risk in mortality observed in the present study does not supersede the fact that DM remains a major risk factor for poor prognosis. It however suggests that the increased risk for worse outcomes is the cumulative effect of DM clustering with other chronic diseases, or cardiometabolic multi-morbidity, which precipitates complications $[25,26]$.

\section{Established predictors and potential factors influencing Covid-19 outcomes}

The present study identified smoking and elevated creatinine as significant predictors in all outcomes of interest (mortality, ICU admission and intubation). Established risk factors such as increasing age, congestive heart failure, bilateral lung infiltrates, high neutrophil count, hyperglycemia and abnormal ALT were also noted to be independent risk factors. Most of these factors have also been linked, in varying degrees, to the progression of acute respiratory distress syndrome (ARDS) secondary to SARS-CoV and MERS-CoV [27]. Together with DM, all these risk factors contribute to the exacerbation of preexisting chronic inflammation, progressing to cytokine storm and rapid impairment of endothelial function, if left untreated [28]. The low prevalence of smoking in the study $(2.6 \%)$ is in alignment with several retrospective observational studies that highlight the unexpectedly low prevalence of smokers among hospitalized patients with Covid-19, but with worse outcomes [29, 30].

Other significant factors for poor outcomes identified in the present study are the use of $\beta$-blockers and severe vitamin $D$ deficiency among admitted Covid-19 patients. Both ACE inhibitor and ARB did not appear to significantly alter the outcomes of interest. One theory is that $\beta$-blockers can be beneficial, albeit controversial, by reducing pulmonary vascular flow, eventually decreasing further damage to the injured lung, among those suspected of ARDS, a common complication among ICU admitted patients [31]. On the other hand, low vitamin D status has been consistently linked to increased risk of pneumonia and upper respiratory tract infections, secondary to weakened immune system and elevated inflammatory cytokines [32]. Accumulating evidence also link vitamin D deficiency to poor Covid-19 prognosis and mortality [33,34]. Despite the lack of sufficient data on the use of vitamin $\mathrm{D}$ for the prevention and treatment of Covid-19, it has nevertheless been advocated as an adjuvant therapy [35]. Given that vitamin D deficiency is very common in the Arab region, especially among the youth [36], further investigations on the effects of vitamin D 
supplementation on outcomes of Covid-19 patients are warranted.

\section{Gender differences in Covid-19 characteristics}

In the present study, men outnumber women in hospital admissions by 2:1. Even if non-Saudis are excluded, more men are still getting hospitalized than women. Men also had a higher prevalence of fever and diarrhea, as well as an over-all worse metabolic profile than women, despite having no differences in clinical outcomes. In contrast, most sexual differences among Covid-19 patients conducted elsewhere highlight similar prevalence in men and women, but with a consistently overwhelming worse outcomes in men in terms of morbidity and mortality, establishing male sex as an independent risk factor for Covid-19 [37-39]. The stronger innate and adaptive immune response in females can be attributed to many factors, but mostly to estrogen being immune boosting as opposed to testosterone, being immune suppressing [40]. The disproportionate number of male hospitalizations in the present study can be attributed to several factors, including the higher number of men in the Saudi population over-all and a higher prevalence of male expatriate residents than females. Another factor is that men in KSA and the Arab region over-all, are more socially mobile, more likely to be employed and not as culturally restricted as their female counterparts, putting them at higher risk for Covid-19, if precautions are ignored.

\section{Strengths and limitations}

The authors acknowledge several limitations. Selection bias is imminent and findings are limited to the accuracy of record keeping, given its retrospective design. The correctness of overlapping comorbidities therefore such as CVD and CHF cannot be established other then what is available in the checklist of medical history and medications taken based on his/her account and/or hospital record. The high prevalence of DM in the present study should be interpreted with caution, since the population is not homogenous, and a considerable number of nonArabs, Indians in particular, who have a different prevalence of DM than Arabs, were included in the analysis. This is important since diabetes and Covid-19 disproportionately affect racial minorities as mentioned previously $[17,18]$. Biochemical parameters such as $25(\mathrm{OH})$ $\mathrm{D}$, to name a few, were absent in most patients and this can affect the findings in terms of decreased power size. Emerging biomarkers in the context of DM and Covid19 management which are not routinely assessed such as $\mathrm{N}$-terminal-pro-Brain Natriuretic peptide, hs-Troponin and TyG index were not measured and may have added clinical value in the study [41, 42]. Furthermore, duration of DM was not noted and the lack of COPD cases may affect the findings, given that these are major confounding variables. Despite the limitations, the findings of the present study are robust, and adds value to the limited literature on Covid-19 patients within the Arab region, as it is the first to comprehensively describe hospitalized patients and differentiates characteristics based on sex, DM status, severity and outcome.

\section{Conclusions}

In summary, the prevalence of DM is high among hospitalized Covid-19 patients in Riyadh, Saudi Arabia. While DM patients have a higher mortality rate than non-DM patients, other factors such as old age, congestive heart failure, smoking, $\beta$-blocker use, the presence of bilateral lung infiltrates, elevated creatinine and severe vitamin $D$ deficiency, appear to be more significant predictors of mortality. Covid-19 patients with either elevated RBG or other acute metabolic impairments (neutrophilia, acute renal and liver dysfunctions) on admission are more likely to receive intensive care. Larger epidemiologic studies covering multiple institutions are needed to determine a more accurate in-hospital death rate in the country.

\section{Supplementary information}

Supplementary information accompanies this paper at https://doi. org/10.1186/s12933-020-01184-4.

Additional file 1: Table S1. Presenting symptoms and vital signs of Covid19 patients according to severity and final outcome.

Additional file 2: Table S2. Clinical characteristics of Covid-19 patients according to severity and outcome.

Additional file 3: Table S3. Factors for outcomes of interest using the multivariate Cox proportional hazards regression model.

\section{Abbreviations}

ACE: Angiotensin converting enzyme; ALT: Alanine transferase; ARB: Angiotensin receptor blockers; ARDS: Acute respiratory distress syndrome; AST: Aspartate aminotransferase; BMI: Body mass index; BUN: Blood urea nitrogen; Ca: Calcium; CCB: Calcium channel blockers; Cl: Confidence interval; CT: Cycle threshold; Covid-19: Coronavirus disease-19; CRP: C-reactive protein; DM: Diabetes mellitus; ER: Emergency room; ESR: Erythrocyte sedimentation rate; FBG: Fasting blood sugar; FT4: Free thyroxine; GLP-1: Glucagon-like peptide-1; HbA1c: Glycated hemoglobin; HDL: High density lipoprotein; HR: Hazards ratio; ICU: Intensive care unit; IL-6: Interleukin-6; IRB: Institutional Review Board; K: Potassium; KSA: Kingdom of Saudi Arabia; KKUH: King Khalid University Hospital; KSUMC: King Khaled University Medical City; LDH: Lactate dehydrogenase; LDL: Low density lipoprotein; MERS-CoV: Middle East Respiratory Syndrome coronavirus; Na: Sodium; NS: Not significant; RT-PCR: Reverse transcription polymerase chain reaction; RBG: Random blood sugar; SARS-CoV: Severe acute respiratory syndrome coronavirus; SARS-CoV2: Severe acute respiratory syndrome coronavirus 2; SpO2: Oxygen saturation; TSH: Thyroid stimulating hormone; VDD: Vitamin D deficiency; WBC: White blood count.

\section{Acknowledgements}

The authors are grateful to the medical residents and nurses for their exceptional support in these exceptional times.

\section{Authors' contributions}

AMA, MEA and AAJ contributed to the study design and conducting the study. MM, SSA, MHA, AA, and SHA contributed to the data collection and 
conducting the study. SS wrote the manuscript and performed data analysis. AMA and NMA contributed to the data interpretation and fund acquisition. AMA is the guarantor of this work, has full access to the data and takes responsibility for the integrity of the data and accuracy of the data analysis. All authors critically reviewed and approved the manuscript in its original, revised and final form. All authors read and approved the final manuscript.

\section{Funding}

The authors extend their appreciation to the Deputyship for Research and Innovation, Ministry of Education in Saudi Arabia for funding this research work through project number IFKSUHI-2020-110.

\section{Availability of data and materials}

The datasets used and/or analyzed during the current study are available from the corresponding author on reasonable request.

\section{Ethics approval and consent to participate}

Informed consent was waived by the Ethics Committee of the College of Medicine in King Saud University in Riyadh, Saudi Arabia (E-20-5090/July 5, 2020).

\section{Consent for publication}

Not applicable.

\section{Competing interests}

The authors declare that they have no competing interests.

\section{Author details}

${ }^{1}$ Division of Endocrinology, Department of Internal Medicine, College of Medicine, King Saud University, Riyadh 11472, Saudi Arabia. ${ }^{2}$ Division of Endocrinology, Diabetes and Metabolism, the Johns Hopkins University, Baltimore, MD 21218, USA. ${ }^{3}$ Strategic Center for Diabetes Research, College of Medicine, King Saud University, Riyadh 11481, Saudi Arabia. ${ }^{4}$ General Directorate of Health Affairs in Eastern Province, Dammam 32247, Saudi Arabia. ${ }^{5}$ King Saud University Medical City, Riyadh 12746, Saudi Arabia. ${ }^{6}$ Obesity, Endocrine, and Metabolism Center, King Fahad Medical City, Riyadh 11564, Saudi Arabia. ${ }^{7}$ Chair for Biomarkers of Chronic Diseases, Biochemistry Department, College of Science, King Saud University, Riyadh 11451, Saudi Arabia.

\section{Received: 24 August 2020 Accepted: 27 November 2020} Published online: 05 December 2020

\section{References}

1. Zhu N, Zhang D, Wang W, et al. A novel coronavirus from patients with pneumonia in China, 2019. N Engl J Med. 2020;382(8):727-33. https://doi. org/10.1056/nejmoa2001017.

2. Dong E, Du H, Gardner L. An interactive web-based dashboard to track COVID-19 in real time. Lancet Infect Dis. 2020;20(5):533-4. https://doi. org/10.1016/\$1473-3099(20)30120-1.

3. Petrosillo N, Viceconte G, Ergonul O, Ippolito G, Petersen E. COVID19, SARS and MERS: are they closely related? Clin Microbiol Infect. 2020;26(6):729-34. https://doi.org/10.1016/j.cmi.2020.03.026.

4. Saudi Arabia Covid-19 Dashboard. https://covid19.moh.gov.sa/. Accessed 13 Oct 2020.

5. Zhou F, Yu T, Du R, et al. Clinical course and risk factors for mortality of adult inpatients with COVID-19 in Wuhan, China: a retrospective cohort study. Lancet. 2020;395(10229):1054-62. https://doi.org/10.1016/S0140 $-6736(20) 30566-3$.

6. Lai PH, Lancet EA, Weiden MD, et al. Characteristics associated with out-of-hospital cardiac arrests and resuscitations during the novel coronavirus disease 2019 pandemic in New York City. JAMA Cardiol. 2020:2020:e202488. https://doi.org/10.1001/jamacardio.2020.2488.

7. Rezende LFM, Thome B, Schveitzer MC, Souza-Júnior PRB, Szwarcwald CL. Adults at high-risk of severe coronavirus disease-2019 (Covid-19) in Brazil. Rev Saude Publica. 2020;54:50. https://doi.org/10.11606/s1518 $-8787.2020054002596$.

8. Docherty AB, Harrison EM, Green CA, et al. Features of 20133 UK patients in hospital with covid-19 using the ISARIC WHO Clinical Characterisation Protocol: prospective observational cohort study. BMJ. 2020;369:1985. https://doi.org/10.1136/bmj.m1985.
9. Alsofayan YM, Althunayyan SM, Khan AA, Hakawi AM, Assiri AM. Clinical characteristics of COVID-19 in Saudi Arabia: a national retrospective study. J Infect Public Health. 2020;S1876-0341 (20):30492-5. https://doi. org/10.1016/j.jiph.2020.05.026.

10. Sardu C, Gargiulo G, Esposito G, Paolisso G, Marfella R. Impact of diabetes mellitus on clinical outcomes in patients affected by Covid-19. Cardiovasc Diabetol. 2020;19(1):76. https://doi.org/10.1186/s12933-020-01047-y.

11. Wu Z, McGoogan JM. Characteristics of and important lessons from the coronavirus disease 2019 (COVID-19) outbreak in China: summary of a report of 72314 cases from the Chinese Center for Disease Control and Prevention. JAMA. 2020;323(13):1239-42. https://doi.org/10.1001/ jama.2020.2648.

12. Reynolds HR, Adhikari S, Pulgarin C, Troxel AB, Iturrate E, Johnson SB, Hausvater A, Newman JD, Berger JS, Bangalore S, Katz SD, Fishman GI, Kunichoff D, Chen Y, Ogedegbe G, Hochman JS. Renin-angiotensinaldosterone system inhibitors and risk of Covid-19. N Engl J Med. 2020;382(25):2441-8. https://doi.org/10.1056/NEJMoa2008975.

13. Saavedra JM. Angiotensin receptor blockers and COVID-19. Pharmacol Res. 2020;156:104832. https://doi.org/10.1016/j.phrs.2020.104832.

14. Schnell O, Standl E, Catrinoiu D, Itzhak B, Lalic N, Rahelic D, Skrha J, Valensi P, Ceriello A. Report from the 4th Cardiovascular Outcome Trial (CVOT) Summit of the Diabetes \& Cardiovascular Disease (D\&CVD) EASD Study Group. Cardiovasc Diabetol. 2019;18(1):30.

15. Habibi J, Aroor AR, Das NA, Manrique-Acevedo CM, Johnson MS, Hayden MR, Nistala R, Wiedmeyer C, Chandrasekar B, DeMarco VG. The combination of a neprilysin inhibitor (sacubitril) and angiotensin-II receptor blocker (valsartan) attenuates glomerular and tubular injury in the Zucker Obese rat. Cardiovasc Diabetol. 2019;18(1):40.

16. Al-Daghri NM, Al-Attas OS, Alokail MS, Alkharfy KM, Yousef M, Sabico SL, Chrousos GP. Diabetes mellitus type 2 and other chronic noncommunicable diseases in the central region, Saudi Arabia (Riyadh cohort 2): a decade of an epidemic. BMC Med. 2011;9:76. https://doi. org/10.1186/1741-7015-9-76.

17. Hussain S, Baxi H, Chand Jamali M, Nisar N, Hussain MS. Burden of diabetes mellitus and its impact on COVID-19 patients: a meta-analysis of real-world evidence. Diabetes Metab Syndr. 2020;14(6):1595-602. https:// doi.org/10.1016/j.dsx.2020.08.014.

18. Caballero AE, Ceriello A, Misra A, Aschner P, McDonnell ME, Hassanein M, Ji L, Mbanya JC, Fonseca VA. COVID-19 in people living with diabetes: an international consensus. J Diabetes Complications. 2020;34(9):107671. https://doi.org/10.1016/j.jdiacomp.2020.107671.

19. Saudi Center for Disease Prevention and Control (Weaaya). Laboratory Diagnosis of COVID-19 in Suspected Cases. https://covid19.cdc.gov.sa/ professionals-health-workers/laboratory-diagnosis/. Accessed 12 Oct 2020

20. Varikasuvu SR, Dutt N, Thangappazham B, Varshney S. Diabetes and COVID-19: a pooled analysis related to disease severity and mortality. Prim Care Diabetes. 2020;S1751-9918(20):30251-5. https://doi. org/10.1016/j.pcd.2020.08.015.

21. Varikasuvu SR, Varshney S, Dutt N. Markers of coagulation dysfunction and inflammation in diabetic and non-diabetic COVID-19. J Thromb Thrombolysis. 2020. https://doi.org/10.1007/s11239-020-02270-w.

22. Shi $Q$, Zhang $X$, Jiang F, Zhang $X$, Hu N, et al. Clinical characteristics and risk factors for mortality of COVID-19 patients with diabetes in Wuhan, China: a two-center. Retrospective study. Diabetes Care. 2020;43(7):138291. https://doi.org/10.2337/dc20-0598.

23. Suleyman G, Fadel RA, Malette KM, et al. Clinical characteristics and morbidity associated with Coronavirus disease 2019 in a series of patients in metropolitan detroit. JAMA Netw Open. 2020;3(6):e2012270. https://doi. org/10.1001/jamanetworkopen.2020.12270.

24. Hillson R. COVID-19: diabetes and death. A call to action. Pract Diabetes. 2020;37(3):76-8. https://doi.org/10.1002/pdi.2271.

25. Maddaloni E, D'Onofrio L, Alessandri F, Mignogna C, Leto G, Pascarella G, Mezzaroma I, Lichtner M, Pozzilli P, Agrò FE, Rocco M, Pugliese F, Lenzi A, Holman RR, Mastroianni CM, Buzzetti R, CoViDiab Study Group. Cardiometabolic multimorbidity is associated with a worse Covid-19 prognosis than individual cardiometabolic risk factors: a multicentre retrospective study (CoViDiab II). Cardiovasc Diabetol. 2020;19(1):164. https://doi. org/10.1186/s12933-020-01140-2.

26. Apicella M, Campopiano MC, Mantuano M, Mazoni L, Coppelli A, Del Prato S. COVID-19 in people with diabetes: understanding the 
reasons for worse outcomes. Lancet Diabetes Endocrinol. 2020;S22138587(20):30238. https://doi.org/10.1016/S2213-8587(20)30238-2.

27. Liu J, Xie W, Wang Y, Xiong Y, Chen S, Han J, Wu Q. A comparative overview of COVID-19, MERS and SARS: review article. Int I Surg. 2020;81:1-8. https://doi.org/10.1016/j.ijsu.2020.07.032.

28. Longo M, Caruso P, Maiorino MI, Bellastella G, Giugliano D, Esposito K. Treating type 2 diabetes in COVID-19 patients: the potential benefits of injective therapies. Cardiovasc Diabetol. 2020;19(1):115. https://doi. org/10.1186/s12933-020-01090-9.

29. Farsalinos K, Barnouni A, Poulas K, Polosa R, Caponnetto P, et al. Current smoking, former smoking, and adverse outcome among hospitalized COVID-19 patients: a systematic review and meta-analysis. Ther Adv Chronic Dis. 2020;11:2040622320935765. https://doi.org/10.1177/20406 22320935765

30. Reddy RK, Charles WN, Sklavounos A, Dutt A, Seed PT, Khajura A. The effect of smoking on COVID-19 severity: a systematic review and metaanalysis. J Med Virol. 2020. https://doi.org/10.1002/jmv.26389.

31. Coppola S, Frojo S, Chiumello D. $\beta$-blockers in critically ill patients: from physiology to clinical evidence. Crit Care. 2015;19:119. https://doi. org/10.1186/s13054-015-0803-2.

32. Weir EK, Thenappan T, Bhargava M, Chen Y. Does vitamin D deficiency increase the severity of COVID-19? Clin Med. 2020;20(4):e107-8. https:// doi.org/10.7861/clinmed.2020-0301.

33. Munshi R, Hussein MH, Toraih EA, Elshazli RM, et al. Vitamin D insufficiency as a potential culprit in critical Covid-19 patients. J Med Virol. 2020. https ://doi.org/10.1002/jmv.26360.

34. Singh SK, Jain R, Singh S. Vitamin D deficiency in patients with diabetes and COVID-19 infection. Diabetes Metab Syndr. 2020;14(5):1033-5. https ://doi.org/10.1016/j.dsx.2020.06.071

35. COVID-19 Treatment Guidelines Panel. Coronavirus Disease 2019 (COVID19) Treatment Guidelines. National Institutes of Health. https://www. covid19treatmentguidelines.nih.gov/. Accessed 13 Oct 2020.
36. Al-Daghri NM, Al-Saleh Y, Aljohani N, et al. Vitamin D deficiency and cardiometabolic risks: a juxtaposition of Arab adolescents and adults. PLoS ONE. 2015;10(7):e0131315. https://doi.org/10.1371/journal.pone.0131315.

37. Jin JM, Bai P, HeW, et al. Gender differences in patients with COVID-19: focus on severity and mortality. Front Public Health. 2020;8:152. https:// doi.org/10.3389/fpubh.2020.00152.

38. Galbadage T, Peterson BM, Awada J, et al. Systematic review and meta-analysis of sex-specific COVID-19 clinical outcomes. Front Med. 2020;7:348. https://doi.org/10.3389/fmed.2020.00348.

39. Strope JD, Chau CH, Figg WD. Are sex discordant outcomes in COVID-19 related to sex hormones? Semin Oncol. 2020;50093-7754(20):30062. https://doi.org/10.1053/j.seminoncol.2020.06.002.

40. Ortona E, Pierdominici M, Rider V. Editorial: sex hormones and gender differences in immune responses. Front Immunol. 2019;10:1076. https:// doi.org/10.3389/fimmu.2019.01076.

41. Ceriello A, Standl E, Catrinoiu D, Itzhak B, Lalic NM, Rahelic D, Schnell O, Škrha J, Valensi P, "Diabetes and Cardiovascular Disease (D\&CVD)” Study Group of the European Association for the Study of Diabetes (EASD). Issues for the management of people with diabetes and COVID-19 in ICU. Cardiovasc Diabetol. 2020;19(1):114. https://doi.org/10.1186/s12933-02001089-2.

42. Ren $H$, Yang Y, Wang F, Yan Y, Shi X, Dong K, Yu X, Zhang S. Association of the insulin resistance marker TyG index with the severity and mortality of COVID-19. Cardiovasc Diabetol. 2020;19(1):58. https://doi.org/10.1186/ s12933-020-01035-2.

\section{Publisher's Note}

Springer Nature remains neutral with regard to jurisdictional claims in published maps and institutional affiliations.
Ready to submit your research? Choose BMC and benefit from:

- fast, convenient online submission

- thorough peer review by experienced researchers in your field

- rapid publication on acceptance

- support for research data, including large and complex data types

- gold Open Access which fosters wider collaboration and increased citations

- maximum visibility for your research: over $100 \mathrm{M}$ website views per year

At BMC, research is always in progress.

Learn more biomedcentral.com/submissions 